\title{
Eosinophils in Eosinophilic Esophagitis: The Road to Fibrostenosis is Paved With Good Intentions
}

\author{
Alfred D. Doyle ${ }^{1 *}$, Mia Y. Masuda ${ }^{1}$, Hirohito Kita ${ }^{1,2}$ and Benjamin L. Wright ${ }^{1,3}$ \\ 1 Division of Allergy, Asthma, and Clinical Immunology, Department of Medicine, Mayo Clinic Arizona, Scottsdale, AZ, \\ United States, ${ }^{2}$ Department of Immunology, Mayo Clinic Arizona, Scottsdale, AZ, United States, ${ }^{3}$ Division of Pulmonology, \\ Phoenix Children's Hospital, Phoenix, AZ, United States
}

OPEN ACCESS

Edited by:

Karen Laky,

National Institutes of Health (NIH)

United States

Reviewed by:

Melanie Anne Ruffner,

Children's Hospital of Philadelphia, United States

Min Wu,

University of North Dakota, United States

*Correspondence:

Alfred D. Doyle

doyle.alfred@mayo.edu

Specialty section: This article was submitted to Molecular Innate Immunity, a section of the journal

Frontiers in Immunology

Received: 06 September 2020 Accepted: 03 November 2020 Published: 01 December 2020

Citation:

Doyle AD, Masuda MY, Kita H and Wright BL (2020) Eosinophils in

Eosinophilic Esophagitis: The

Road to Fibrostenosis is Paved

With Good Intentions.

Front. Immunol. 11:603295. doi: 10.3389/fimmu.2020.603295
Eosinophilic esophagitis (EoE) is an antigen-driven disease associated with epithelial barrier dysfunction and chronic type 2 inflammation. Eosinophils are the defining feature of EoE histopathology but relatively little is known about their role in disease onset and progression. Classically defined as destructive, end-stage effector cells, eosinophils (a resident leukocyte in most of the Gl tract) are increasingly understood to play roles in local immunity, tissue homeostasis, remodeling, and repair. Indeed, asymptomatic esophageal eosinophilia is observed in IgE-mediated food allergy. Interestingly, EoE is a potential complication of oral immunotherapy (OIT) for food allergy. However, we recently found that patients with peanut allergy may have asymptomatic esophageal eosinophilia at baseline and that peanut OIT induces transient esophageal eosinophilia in most subjects. This is seemingly at odds with multiple studies which have shown that EoE disease severity correlates with tissue eosinophilia. Herein, we review the potential role of eosinophils in EoE at different stages of disease pathogenesis. Based on current literature we suggest the following: (1) eosinophils are recruited to the esophagus as a homeostatic response to epithelial barrier disruption; (2) eosinophils mediate barrierprotective activities including local antibody production, mucus production and epithelial turnover; and (3) when type 2 inflammation persists, eosinophils promote fibrosis.

Keywords: eosinophilic esophagitis, eosinophil, food allergy, oral immunotherapy, epithelial barrier, fibrosis, esophagus

\section{INTRODUCTION}

Eosinophilic esophagitis (EoE) is an increasingly prevalent disease entity clinically characterized by symptoms of esophageal dysfunction (1). Endoscopically, EoE is defined by the presence of edema, longitudinal furrows, exudates, and rings and esophageal narrowing in more advanced disease (2). Histopathologic diagnosis requires the presence of esophageal eosinophilia with a tissue eosinophil 
density $\geq 15$ eos/hpf (1). Patients with EoE are often atopic and up to $70 \%$ may have IgE-mediated food allergy (3-5). Treatments for EoE include high-dose proton-pump inhibitors, swallowed topical steroids, dietary elimination, and esophageal dilation (6). While there are no FDA-approved therapies for EoE, a number of clinical trials investigating biologic agents are ongoing (7). In terms of its pathogenesis, EoE is driven primarily by food antigens $(8,9)$ and less commonly environmental allergens $(10,11)$; however, EoE does not appear to be IgE-mediated (12). Recent literature suggests that EoE is associated with impaired epithelial barrier function of the esophageal mucosa (13-15). Barrier disruption may alter local antigen processing leading to chronic type 2 inflammation and dysregulation of endogenous protease activity $(16,17)$. These inflammatory responses (including eosinophilia) may subsequently give rise to a perpetual cycle of remodeling and repair.

\section{ORAL IMMUNOTHERAPY AND THE INITIATION OF EOE}

OIT for IgE-mediated food allergy represents a unique vantage point from which to understand the pathogenesis of EoE. OIT is based on the principle that graduated antigen exposure desensitizes acute effector cells (e.g. mast cells, basophils) and modulates antigen-specific $\mathrm{T}$ - and B-cell responses allowing for ingestion of pre-defined doses of a triggering food protein (18). Importantly, approximately $50 \%$ of subjects receiving OIT develop gastrointestinal symptoms and up to 5\% develop EoE $(19,20)$. Generally, EoE resolves with cessation of OIT; however, some subjects develop persistent disease $(21,22)$. The prevalence of EoE among patients with food allergy is substantially increased compared to the general population and subjects do not routinely undergo upper endoscopy before starting OIT; therefore, it is difficult to exclude the possibility that OIT subjects have pre-existing subclinical EoE (5).

To address this, we performed a study analyzing longitudinal endoscopic biopsies during a 2-year clinical OIT trial in adults with IgE-mediated peanut allergy $(23,24)$. We observed that some subjects did, indeed, have asymptomatic esophageal eosinophilia

\footnotetext{
Abbreviations: EoE, Eosinophilic esophagitis; GI, Gastrointestinal; OIT, Oral immunotherapy; FDA, Food and Drug Administration; Ig, Immunoglobulin; EoEe, EoE endotype; IL, Interleukin; TSLP, Thymic stromal lymphopoietin; MBP, Major basic protein; EPX, Eosinophil peroxidase; TGF, Transforming growth factor; ILC, Innate lymphoid cell; LPS, Lipopolysaccharide; S. aureus, Staphylococcus aureus; C5a, Complement component 5a; EETs, Eosinophil extracellular traps; DNA, Deoxyribonucleic acid; EMT, epithelial-mesenchymal transition; MMP, Matrix metalloproteinase; MHC, Major histocompatibility complex; CD, Cluster of differentiation; GM-CSF, Granulocyte-macrophage colony-stimulating factor; PG, Prostaglandin; CRTH2, Prostaglandin D2 receptor; Th, T helper; VEGF, Vascular endothelial growth factor; NGF, Nerve growth factor; EDN, Eosinophil-derived neurotoxin; IFN, Interferon; TNF, Tumor necrosis factor; APRIL, A proliferation-inducing ligand; BAFF, B-cell activating factor; SCF, Stem cell factor; FGF, Fibroblast growth factor; HB-EGF, Heparinbinding EGF-like growth factor; PDGF, Platelet-derived growth factor; VIP, Vasoactive intestinal peptide; DAO, Diamine oxidase; ALOX, arachidonate lipoxygenase; IDO, Indoleamine 2,3-dioxygenase; ECP, Eosinophil cationic protein; PAF, Platelet activating factor; CCL, C-C motif chemokine; CXCL, C$\mathrm{X}-\mathrm{C}$ motif chemokine.
}

( $\geq 15$ eos/hpf) at baseline; eosinophils are not present in the normal esophagus. Tissue eosinophilia was associated with mild endoscopic abnormalities (rings, edema, linear furrows) as well as other histopathologic alterations (basal zone hyperplasia). Importantly, while a few subjects had tissue eosinophilia at baseline, all subjects had evidence of dilated intercellular spaces in at least one segment of the esophagus suggesting IgE-mediated food allergy is also associated with epithelial barrier disruption of the esophagus. When participants were followed longitudinally, OIT induced or exacerbated esophageal eosinophilia in almost all subjects. Intriguingly, esophageal eosinophilia was transient in most subjects despite the fact that antigen exposure with OIT was continued. For a majority, tissue eosinophilia was mild and asymptomatic, although one patient developed dysphagia and food impaction and was diagnosed with EoE. The only other subject with persistent esophageal eosinophilia failed the final desensitization challenge after two years of peanut OIT.

The esophageal eosinophilia observed in OIT subjects is usually asymptomatic and transient. However, it is unclear to what extent or when this may occur in EoE subjects. We hypothesize that patients diagnosed with EoE have more profound epithelial barrier impairment and/or dysfunctional wound healing and repair responses that perpetuate type 2 inflammatory responses. It remains an open question as to whether controlled, graduated antigen exposure can desensitize EoE subjects to trigger foods. This is the rationale for recent studies of epicutaneous therapy in EoE (25).

In addition to clinical and histologic features, OIT and EoE subjects share similar immunologic characteristics. For example, OIT induces food-specific IgA and IgG4 responses in saliva and peripheral blood $(26,27)$. These markers are also increased in the saliva, biopsy homogenates and peripheral blood of patients with EoE (28-30). Importantly, food-specific IgA and IgG4 levels are associated with the development of sustained unresponsiveness to food challenge following OIT (27).

Overlaps in the clinical and histopathologic features of OIT and EoE subjects suggest that food allergy and EoE exist on the same disease spectrum. Taken together, these observations suggest that: (1) IgE-mediated food allergy, like EoE, is associated with epithelial barrier dysfunction of the esophagus; (2) antigen exposure in this context promotes tissue eosinophilia; (3) esophageal eosinophilia during OIT is often asymptomatic; and (4) antigen-driven tissue eosinophilia can resolve or persist resulting in EoE. We hypothesize that eosinophils are recruited initially during OIT to restore homeostasis; however, when tissue inflammatory and remodeling responses become dysregulated they contribute to EoE pathogenesis (Figure 1).

\section{EOE ENDOTYPES AND DISEASE PROGRESSION}

Similar to asthma, EoE may be clustered into different endotypes using clinical, endoscopic, histopathologic, and molecular features. A single, multi-site cross-sectional study of endoscopic, histologic, and molecular data from esophageal biopsies identified three discrete EoE endotypes (31). EoE endotype 1 (EoEe1) has a 
normal endoscopic appearance and is usually steroid-sensitive. Markers of inflammation and epithelial differentiation are relatively unchanged in this endotype. EoE endotype 2 (EoEe2) is usually pediatric-onset, associated with atopy, and steroidrefractory. Gene expression in EoEe2 is notable for marked upregulation of pro-inflammatory mediators (e.g. IL-4 and TSLP). EoE endotype 3 (EoEe3) tends to be adult-onset, non-atopic, and is associated with fibrostenosis and narrow-caliber esophagus. Gene expression in this group denotes loss of epithelial differentiation. Among the endotypes, EoEel is the most benign, while EoEe2 is associated with marked type 2 inflammation. Unsupervised clustering of cytokine gene expression suggests these endotypes may be further subdivided into additional subgroups (32). Of note, validation and verification of these endotypes requires further study and natural history studies have not followed EoE cohorts longitudinally in order to understand specific relationships between endotypes; however, these EoE endotypes may represent different points of progression across a continuum of disease. This same principle may be reflected in the fact that children have nonspecific gastrointestinal symptoms; whereas, food impaction due to fibrostenosis is much more common in teens and adults.

\section{LESSONS FROM TARGETING EOSINOPHILS AND EOE-LIKE DISEASE}

Unsuccessful clinical trials targeting eosinophils and EoE-like disease provide two lines of evidence supporting the hypothesis

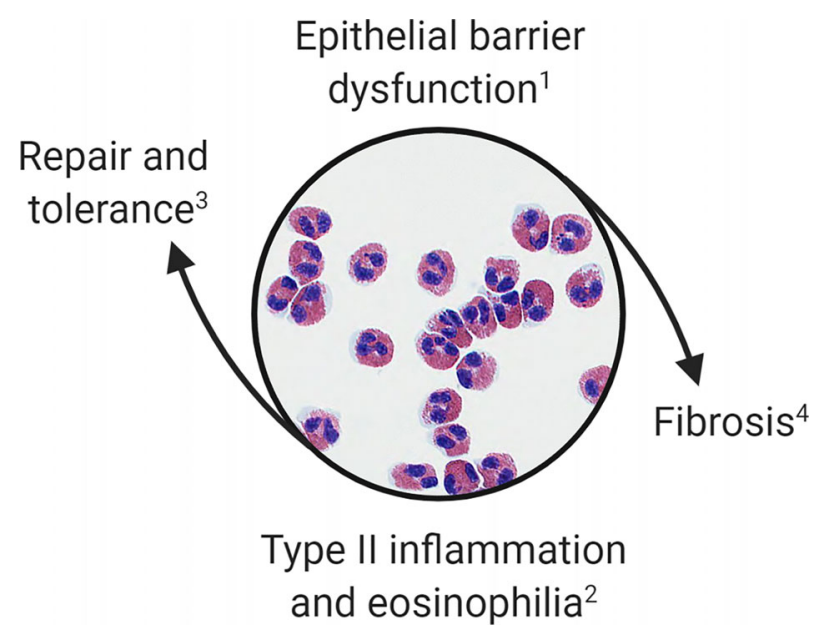

FIGURE 1 | Proposed model of esophageal eosinophilia. Eosinophils are initially recruited to the esophagus to restore barrier function. When inflammatory and remodeling responses become dysregulated eosinophils contribute to type 2 inflammation, worsening of barrier integrity, and fibrosis. This paradigm allows for categorization of (1) patients with IgE-mediated food allergy or subclinical barrier dysfunction; (2) OIT patients, EoEe1, and EoEe2 representing asymptomatic, mild or severe phases of the inflammatory response; (3) OIT patients who successfully develop sustained unresponsiveness or those who naturally outgrow a food allergy; and (4) EoEe3, which is characterized by fibrostenosis. that eosinophils may be dispensable in EoE pathology. Given their conspicuous presence in tissue pathology, early clinical trials of biologics in EoE focused on depletion of eosinophils. IL-5 promotes eosinophil maturation, proliferation, activation, and survival (33); therefore, targeting this cytokine pathway was a logical first step. Three anti-IL-5 agents, mepolizumab, reslizumab, and benralizumab, have been developed. Mepolizumab and reslizumab neutralize IL- 5 by binding it directly preventing interaction with IL-5R $\alpha$. Benralizumab binds to IL-5R $\alpha$ blocking interaction with IL-5 and promoting antibodydependent cellular cytotoxicity (ADCC) and deletion of eosinophils. In an alternative strategy, lirentelimab targets siglec8. Siglec- 8 is a transmembrane protein shared by eosinophils and mast cells. Ligation of siglec- 8 induces apoptosis of eosinophils and inhibits mast cell activity. Lirentelimab both mediates these activities and induces ADCC of eosinophils (34).

Promising results of an open label trial of mepolizumab in 4 patients with EoE led to the first randomized, double-blind, placebo-controlled (DBPC) trial of mepolizumab in 11 patients $(35,36)$. The results of this clinical trial were notable for reductions in tissue eosinophil counts but limited clinical improvement in EoE symptoms. A subsequent prospective trial randomized 59 pediatric subjects with EoE to three different dosing arms, using the lowest dose of mepolizumab as a comparator, as opposed to a placebo group (37). While the investigators demonstrated reductions in tissue eosinophilia, again there were no significant differences in clinical symptoms between treatment arms. In the largest randomized DBPC trial of anti-IL-5 therapy in EoE to date, 226 pediatric subjects received reslizumab and, again, significant improvements in clinical symptoms were not seen in the treatment arm compared to placebo (38). Importantly, despite overall reductions in tissue eosinophilia, in each of these trials a majority of subjects did not achieve histologic remission (peak tissue eosinophil counts $<15 \mathrm{eos} / \mathrm{hpf}$ ). Indeed, mepolizumab and reslizumab appear to have greater effects on peripheral blood eosinophils compared to esophageal tissue eosinophils [e.g. 90 vs $55 \%$ reduction respectively with mepolizumab (39)]. Together, the outcomes of these trials suggest that eosinophils do not exclusively mediate tissue pathology in EoE or incomplete eosinophil depletion accounts for the persistence of symptoms. Trials of benralizumab and lirentelimab, drugs more likely to completely deplete tissue eosinophils, may be more informative.

Additional evidence that eosinophils may not be the primary driver of clinical symptoms is the existence of EoE-like disease; an entity characterized by EoE symptoms responsive to swallowed topical corticosteroids, but without tissue eosinophilia (40). Kindred of patients with EoE-like disease often reveal multiple family members affected with EoE. Generally, these patients do not have advanced endoscopic findings and their histopathology reveals papillary elongation with increased $\mathrm{T}$ cells. These patients are distinguished from EoE patients by reduced eotaxin-3 expression. Finally, patients with EoE-like disease may evolve to develop classical EoE. It is tempting to speculate that EoE-like disease represents yet another endotype on the EoE spectrum. Molecular studies comparing patients with EoE-like disease, food allergy, and EoEe1 are needed to evaluate disease overlap. 


\section{ROLES OF EOSINOPHILS IN EOE}

Eosinophils are often considered destructive end-stage effector cells defined by their ability to release toxic granule proteins that can damage surrounding tissue. However, comprehensive reviews of eosinophil activities suggest a much more complex cell with roles in health and disease (41-45). As shown in Table 1, eosinophils produce and release various mediators that are involved in inflammation, immunoregulation, and tissue remodeling and repair. In EoE, levels of tissue eosinophilia correlate with disease severity as well as response to treatments $(156,164)$. On the other hand, eosinophils clearly have a homeostatic or physiologic role as resident cells in the rest of the GI tract and findings from EoE-like disease along with the limited effectiveness of anti-IL-5 therapy suggest a minor role in clinical symptoms in EoE. Moreover, we have recently identified asymptomatic eosinophilia in the esophagus of OIT subjects at baseline. These seemingly divergent observations can be explained by considering the temporal effects of eosinophil activities throughout the progression of EoE. Specifically, we propose that the appearance of eosinophils in the esophagus begins as an extension to their homeostatic function in other GI tissues to enhance barrier function. These eosinophils may become activated to contribute to further protective activities and wound repair and, over time, contribute to disease pathology and fibrosis.

Eosinophil activities in allergic disease are well studied, particularly in asthma, with identified roles for inflammation (e.g. MBP, IL-13), mucus production (IL-13), epithelial damage (MBP, EPX), tissue remodeling/fibrosis (IL-13, TGF- $\beta$ ), and smooth muscle hyperresponsiveness (IL-13, leukotrienes) (165, 166). These pathways have also been observed in EoE by examination of patient biopsies, cell culture experiments, and mouse models. The many potential roles of eosinophils in EoE are well reviewed (67, 167-174). Below we highlight examples of eosinophil activities in barrier maintenance, defense, repair, and fibrosis that suggest esophageal eosinophilia is a protective response that becomes problematic over time.

\section{EARLY PHASE/PROTECTIVE RESPONSE IN EOE}

\section{Recruitment of Eosinophils}

The epithelial barrier has been implicated as central to the disease process in EoE $(13,175)$. While initiating events remain unclear in EoE, environmental insults to the epithelium (e.g. allergens) can trigger the release of inflammatory signaling molecules including TSLP, IL-25, and IL-33 [all shown to be elevated in EoE (79)] that promote a type 2 inflammatory response [e.g. IL-13 production by ILC2s $(176,177)]$ which leads to production of eosinophil chemotactic factors, particularly eotaxin-3 (178).

\section{Eosinophils and Epithelial Barrier Maintenance}

Eosinophils have been linked with a host of activities that help to protect/restore the epithelial barrier including antimicrobial defenses, remodeling and repair activities, and immune regulation. Mice deficient for eosinophils have shown that under homeostatic conditions eosinophils support mucus-secreting goblet cell numbers in the small intestine (50). Expression of certain mucins has been shown to be upregulated in biopsies of patients with EoE and EoE mouse models [e.g $(51,179)$.] but further investigation is needed to understand the activities of esophageal glands that are located beyond the reach of these biopsies (i.e. in the lamina propria and submucosa). Interestingly, in our experience with mouse and pig models of EoE, eosinophils tend to accumulate in the lamina propria similar to the rest of the GI tract (unpublished observations). Notably, IL-5 induced esophageal eosinophilia in a transgenic mouse model was not sufficient to induce pathology but with additional stimulus from a hapten increased epithelial layer eosinophilia was observed along with pathologies associated with EoE (180). In humans, a recent retrospective study of esophageal biopsies utilizing specialized forceps that enabled more reliable subepithelial sampling found that one-third of subjects demonstrated greater subepithelial eosinophil density as compared to the epithelium $(181,182)$. These observations suggest a likely unappreciated level of eosinophils in the esophageal lamina propria. Further investigation is needed to understand the role of subepithelial esophageal eosinophilia in disease pathogenesis.

\section{Eosinophils and Epithelial Barrier Defense}

Eosinophils have been shown to directly mediate host antimicrobial defense activities in the gut. For example, in response to activation with LPS, S. aureus, C5a, or TSLP, eosinophils release eosinophil extracellular traps (EETs). EETs are mitochondrial DNA laced with toxic eosinophil granule proteins (i.e. MBP, EPX, EDN, ECP) that are released into the extracellular space and can bind and kill bacteria. Indeed, hypereosinophilic mice exhibited local extracellular DNA deposition and were protected against sepsis after cecal ligation and puncture (183). Notably, EETs were detected in the esophagus of active EoE subjects (79), suggesting a role for this mechanism in protection against microbes in EoE. In addition, MBP and IL-13 in particular induce epithelial turnover, an effective mechanism for expulsion of organisms/substances and replacement of damaged epithelium $(126,184)$.

\section{Eosinophils and Epithelial Barrier Repair/ Immune Tolerance}

As shown in Table 1, eosinophils can produce factors that help to restore the barrier by promoting epithelial to mesenchymal transition (EMT) which facilitates wound repair. These factors may include, but are not limited to, TGF- $\beta$ (92), MMP-9 (114), IL-4 (185), IL-13 (185), EPX (127), and MBP (92, 93, 186). IL-13 in particular is considered a central mediator in $\operatorname{EoE}(68,69)$ and IL-13 expressing eosinophils have been identified in the esophageal tissue of EoE subjects (185). Notably, IL-33 promotes IL-13 production by eosinophils (70, 187-190). Recently, IL-13 has been shown to upregulate synaptopodin, an actin-associated protein associated with wound healing, and barrier integrity, in the epithelium of EoE subjects (71). Eosinophils can also modulate the immune response to 
TABLE 1 | Protective and pathologic effects of eosinophil-derived mediators.




TABLE 1 | Continued

\section{Eosinophil-derived Mediator}

Substance P
VIP
$\alpha$-defensin
Angiogenin
MMP-9
Heparanase
DAO (histaminase)
15-lipoxygenase derivatives
(e.g ALOX15).

(e.g ALOX15).

IDO

Superoxide $\left(\mathrm{O}_{2}^{-}\right)$

MBP-1



EPX

ECP

EDN

CLC

EET's

PAF

Thromboxane B2

Leukotriene C4

PGD2

PGE2

PGF2 $\alpha$

Protectin D1

CCL17 (TARC)

CCL22 (MDC)

CCL5 (RANTES)

CCL11 (eotaxin-1)

CXCL5 (ENA-78)

\section{CXCL1 (GRO- $\alpha)$}

Wound repair

CCL2 (MCP-1)

CCL23 (MIP-1 $\alpha$ )

CCL4 (MIP-1 $\beta$ )

CXCL9 (MIG)

CXCL10 (IP10)

\section{Protective effects}

Wound repair

Smooth muscle relaxation

Antimicrobial

Wound repair

IL-1 $\beta$, TGF- $\beta$ activation

Wound repair

Resolution of inflammation

Resolution of inflammation arachidonic acid metabolism

Immune tolerance

Antimicrobial

Antimicrobial

epithelial hyperplasia/proliferation (FGF-9)

Antimicrobial

Antimicrobial

Antimicrobial

Antimicrobial

Antimicrobial

Barrier function: mucus production

Resolution of inflammation

Resolution of inflammation

\section{Pathologic effects}

References*

Pain

inflammation

angiogenesis

Inflammation: innate immune activation

Angiogenesis

IL-1 $\beta$, TGF- $\beta$ activation

Inflammation

angiogenesis

(108)

(108, 109)

$(110,111)$

$(99,112,113)$

$(114,115)$

(116-118)

(119)

(120-123)

Inflammation

angiogenesis

$(124,125)$

Inflammation

Cytotoxic

barrier dysfunction

smooth muscle activation

inflammation: mast cell/basophil degranulation

fibrosis

Cytotoxic

inflammation: mast cell activation

$(127,130$,

fibrosis

Inflammation: mast cell activation

neurotoxic

cytotoxic

Inflammation: dendritic cell activation (132, 136-

neurotoxic

138)

Inflammation: carrier for other eosinophil granule

cationic RNases

$(32,132,139$

Contain toxic granules - see above

140)

Inflammation

(79)

Smooth muscle activation

(141)

Smooth muscle activation

(142)

inflammation

Inflammation

$(143,144)$

Inflammation

(145)

pain

(142)

Smooth muscle activation

$(146,147)$

inflammation

Inflammation

Inflammation

$(148,149)$

Inflammation

$(150,151)$

$(150,151)$

Inflammation

$(152,153)$

Inflammation

(154)

angiogenesis

Inflammation

angiogenesis

(155)

Inflammation

49, 62, 156

158)

Inflammation

$(159,160)$

Inflammation

$(49,84,161)$

Inflammation

(62, 159, 162)

Inflammation
(163)

(163)

*Each mediator has references listed that support production by eosinophils. Additional references implicate certain mediators in EoE, though the source may not be identified. 
facilitate barrier repair. Indeed, mice deficient for eosinophils have established that eosinophils support IgA production (50, 88), which in turn, is secreted to the lumen to facilitate barrier function. Notably, food-specific IgA is increased in EoE (30). Finally, eosinophils expressing MHCII and CD80 have been identified in EoE subjects $(191,192)$ and may present antigen to T cells. TGF- $\beta$ and IL-10 can influence the production of IgA, IgG4, and $\mathrm{T}$ regulatory cell responses. Both cytokines are produced by eosinophils in $\mathrm{EoE}(92,185)$ but a mechanistic link remains to be established.

\section{CHRONIC PHASE/PATHOLOGIC ACTIVITIES IN EOE}

During the chronic phase of the disease, eosinophil activities may contribute to inflammation, tissue remodeling, and fibrosis. Eosinophil-derived mediators that are helpful in barrier defense and repair can, over time, contribute to these activities.

\section{Eosinophils and Inflammation}

Eosinophils may promote sustained eosinophilic inflammation by production of eosinophil survival factors GM-CSF and IL-5, expression of which has been observed in tissue eosinophils from EoE subjects (185). The eosinophil microenvironment may become problematic for the epithelium with chronic inflammation-for example, eosinophil oxygen metabolism may induce tissue hypoxia resulting in barrier impairment (193). Eosinophils are also a source of IL-9 and have been linked with mast cell numbers in the esophagus (63) which are, in turn, linked with disease severity (194). Interestingly, mast cell numbers are increased in EoE as compared to EoE-like disease (40). In addition, eosinophils produce eicosanoids including PGD2. PGD2 signals through CRTH2, which has been shown to support ILC2 accumulation (195). CRTH2 has also been shown to be expressed by a subset of IL-5 and IL-13 producing Th2 cells in EoE (196). Interestingly, elevated numbers of $\mathrm{CRTH} 2+\mathrm{CD} 4+\mathrm{T}$ cells are observed in EoE as compared to EoE-like disease (40). Finally, eosinophil granule proteins including MBP can damage epithelium resulting in increased pro-inflammatory mediators (197) and have been shown to reduce barrier integrity in the colonic epithelium (128). MBP also can induce mast cell and basophil degranulation as well as smooth muscle and fibroblast activation $(129,198-200)$ thereby contributing to inflammation and fibrosis.

\section{Eosinophils and Remodeling/Fibrosis}

Chronic IL-13-mediated wound healing activities may become problematic. For example, IL-13 induced synaptopodin overexpression has been shown to impair barrier integrity and reduce epithelial differentiation (71). IL-13 is also linked with epithelial barrier disruption by downregulation of epithelial junction molecules and upregulation of the protease calpain-14 (201). Phase 2 trials of biologics targeting IL-13 pathways have demonstrated improvement in endoscopic and histologic findings in EoE (202-204). Data from mouse models of EoE crossed with eosinophil deficient lines suggest a role for eosinophils in hyperplasia and fibrosis in an allergen-driven model $(179,205)$ while no role was observed in an IL-13 overexpression model (206). Together these findings would be consistent with a role for eosinophil-derived IL-13 in these remodeling activities that are hallmark pathological features of human EoE (206). Notably, eosinophil-derived IL-13 caused extensive remodeling in the mouse lung by promoting MMP-12 production, a mediator identified as elevated in EoE (120, 207). The activities of MMP-12 in human EoE require investigation. Eosinophil-derived factors IL13 and TGF- $\beta$ (and others including IL-1 $\beta$, and IL-4) induce fibroblast to myofibroblast differentiation and eosinophil-derived TGF- $\beta$ in particular is linked with production of collagen $(46,208$, 209). TGF- $\beta$ also can induce smooth muscle proliferation, hyperplasia, and contraction (210) which may contribute to esophageal dysmotility. Finally, activated eosinophils produce angiogenic factors such as VEGF and nerve remodeling factors such as NGF and EDN which may contribute to nerve growth and cytotoxicity, respectively.

\section{DISCUSSION}

The role(s) of eosinophils remains unclear in EoE. The observations we and others have made show asymptomatic eosinophilia is likely to be a common occurrence. This suggests that, like other areas of the GI tract, eosinophils may promote tissue homeostasis. Eosinophil activities in EoE and other diseases suggest a role for protecting/ restoring the barrier. However, if the barrier is not restored it is likely that eosinophils contribute to inflammation and remodeling/fibrosis. Notably, many of the eosinophil-derived mediators discussed herein have wound healing barrier restoring activities in addition to being linked with pathologies associated with chronic inflammation such as fibrosis. Thus, we suggest the road to fibrostenosis is paved with good intentions. These observations also suggest it may be important to target eosinophils based on EoE endotype. Conceivably targeting those with the fibrostenotic EoE (EoEe3) may result in reduced chronic remodeling pathology while sparing subjects in whom eosinophils may primarily benefit esophageal barrier function. In addition, our perspective suggests therapeutic strategies aimed at protecting, improving, or restoring barrier function by promoting homeostatic eosinophil pathways (e.g. mucus and antibody production) may be helpful.

\section{AUTHOR CONTRIBUTIONS}

$\mathrm{AD}$ and $\mathrm{BW}$ drafted the manuscript. MM contributed to the content of the table. $\mathrm{AD}, \mathrm{MM}, \mathrm{HK}$, and $\mathrm{BW}$ reviewed and provided critical feedback on the manuscript. All authors contributed to the article and approved the submitted version.

\section{FUNDING}

This study is supported by the Don and Kathy Levin Family Foundation (ADD, MYM, BLW), Mayo Clinic Foundation 
(BLW, HK), Phoenix Children's Hospital Foundation (BLW), Arizona Biomedical Research Consortium (ADHS18-198880) (BLW). Dr. Wright is a scholar in the Consortium of Eosinophilic Gastrointestinal Disease Researchers (CEGIR). CEGIR (U54 AI117804) is part of the Rare Disease Clinical Research Network (RDCRN), an initiative of the Office of Rare Diseases Research (ORDR), NCATS, and is funded through collaboration between NIAID, NIDDK, and NCATS. CEGIR is also supported by patient advocacy groups including American Partnership for Eosinophilic Disorders (APFED), Campaign Urging Research for Eosinophilic Diseases (CURED), and Eosinophilic Family Coalition (EFC). As a member of the

\section{REFERENCES}

1. Dellon ES, Liacouras CA, Molina-Infante J, Furuta GT, Spergel JM, Zevit N, et al. Updated International Consensus Diagnostic Criteria for Eosinophilic Esophagitis: Proceedings of the AGREE Conference. Gastroenterology (2018) 155(4):1022-33 e10. doi: 10.1053/j.gastro.2018.07.009

2. Hirano I, Moy N, Heckman MG, Thomas CS, Gonsalves N, Achem SR. Endoscopic assessment of the oesophageal features of eosinophilic oesophagitis: validation of a novel classification and grading system. Gut (2013) 62(4):489-95. doi: 10.1136/gutjnl-2011-301817

3. Chehade M, Jones SM, Pesek RD, Burks AW, Vickery BP, Wood RA, et al. Phenotypic Characterization of Eosinophilic Esophagitis in a Large Multicenter Patient Population from the Consortium for Food Allergy Research. J Allergy Clin Immunol Pract (2018) 6(5):1534-44 e5. doi: 10.1016/j.jaip.2018.05.038

4. Leigh LY, Spergel JM. An in-depth characterization of a large cohort of adult patients with eosinophilic esophagitis. Ann Allergy Asthma Immunol (2019) 122(1):65-72 el. doi: 10.1016/j.anai.2018.09.452

5. Hill DA, Dudley JW, Spergel JM. The Prevalence of Eosinophilic Esophagitis in Pediatric Patients with IgE-Mediated Food Allergy. J Allergy Clin Immunol Pract (2017) 5(2):369-75. doi: 10.1016/j.jaip.2016.11.020

6. Rank MA, Sharaf RN, Furuta GT, Aceves SS, Greenhawt M, Spergel JM, et al. Technical Review on the Management of Eosinophilic Esophagitis: A Report From the AGA Institute and the Joint Task Force on AllergyImmunology Practice Parameters. Gastroenterology (2020) 158(6):1789-810 e15. doi: 10.1016/j.anai.2020.03.021

7. Wechsler JB, Hirano I. Biological therapies for eosinophilic gastrointestinal diseases. J Allergy Clin Immunol (2018) 142(1):24-31 e2. doi: 10.1016/ j.jaci.2018.05.018

8. Kelly KJ, Lazenby AJ, Rowe PC, Yardley JH, Perman JA, Sampson HA. Eosinophilic esophagitis attributed to gastroesophageal reflux: improvement with an amino acid-based formula. Gastroenterology (1995) 109(5):1503-12. doi: 10.1016/0016-5085(95)90637-1

9. Markowitz JE, Spergel JM, Ruchelli E, Liacouras CA. Elemental diet is an effective treatment for eosinophilic esophagitis in children and adolescents. Am J Gastroenterol (2003) 98(4):777-82. doi: 10.1111/j.1572-0241.2003.07390.x

10. Reed CC, Iglesia EGA, Commins SP, Dellon ES. Seasonal exacerbation of eosinophilic esophagitis histologic activity in adults and children implicates role of aeroallergens. Ann Allergy Asthma Immunol (2019) 122(3):296-301. doi: 10.1016/j.anai.2018.12.013

11. Ram G, Lee J, Ott M, Brown-Whitehorn TF, Cianferoni A, Shuker M, et al. Seasonal exacerbation of esophageal eosinophilia in children with eosinophilic esophagitis and allergic rhinitis. Ann Allergy Asthma Immunol (2015) 115(3):224-8 e1. doi: 10.1016/j.anai.2015.07.004

12. Clayton F, Fang JC, Gleich GJ, Lucendo AJ, Olalla JM, Vinson LA, et al. Eosinophilic esophagitis in adults is associated with IgG4 and not mediated by IgE. Gastroenterology (2014) 147(3):602-9. doi: 10.1053/j.gastro.2014.05.036

13. Rochman M, Azouz NP, Rothenberg ME. Epithelial origin of eosinophilic esophagitis. J Allergy Clin Immunol (2018) 142(1):10-23. doi: 10.1016/ j.jaci.2018.05.008
RDCRN, CEGIR is also supported by its Data Management and Coordinating Center (DMCC) (U2CTR002818).

\section{ACKNOWLEDGMENTS}

The authors would like to thank the Levin Family for their support of food allergy research at Mayo Clinic Arizona. This work is dedicated to our friend and colleague Michael "Mike" McGarry. Mike was an excellent mentor providing deep insight into eosinophil biology and broad expertise in hematology. We will miss Mike's mentorship, curiosity, good nature, and hearty laugh.

14. Rothenberg ME, Spergel JM, Sherrill JD, Annaiah K, Martin LJ, Cianferoni A, et al. Common variants at $5 \mathrm{q} 22$ associate with pediatric eosinophilic esophagitis. Nat Genet (2010) 42(4):289-91. doi: 10.1038/ng.547

15. Kottyan LC, Davis BP, Sherrill JD, Liu K, Rochman M, Kaufman K, et al. Genome-wide association analysis of eosinophilic esophagitis provides insight into the tissue specificity of this allergic disease. Nat Genet (2014) 46(8):895-900. doi: 10.1038/ng.3033

16. O'Shea KM, Aceves SS, Dellon ES, Gupta SK, Spergel JM, Furuta GT, et al. Pathophysiology of Eosinophilic Esophagitis. Gastroenterology (2018) 154 (2):333-45. doi: 10.1053/j.gastro.2017.06.065

17. Azouz NP, Klingler AM, Pathre P, Besse JA, Baruch-Morgenstern NB, Ballaban AY, et al. Functional role of kallikrein 5 and proteinase-activated receptor 2 in eosinophilic esophagitis. Sci Transl Med (2020) 12(545): eaaz7773. doi: 10.1126/scitranslmed.aaz7773

18. Kulis MD, Patil SU, Wambre E, Vickery BP. Immune mechanisms of oral immunotherapy. J Allergy Clin Immunol (2018) 141(2):491-8. doi: 10.1016/ j.jaci.2017.12.979

19. Investigators PGoC, Vickery BP, Vereda A, Casale TB, Beyer K, du Toit G, et al. AR101 Oral Immunotherapy for Peanut Allergy. N Engl J Med (2018) 379(21):1991-2001. doi: 10.1056/NEJMoa1812856

20. Petroni D, Spergel JM. Eosinophilic esophagitis and symptoms possibly related to eosinophilic esophagitis in oral immunotherapy. Ann Allergy Asthma Immunol (2018) 120(3):237-40 e4. doi: 10.1016/j.anai.2017.11.016

21. Lucendo AJ, Arias A, Tenias JM. Relation between eosinophilic esophagitis and oral immunotherapy for food allergy: a systematic review with meta-analysis. Ann Allergy Asthma Immunol (2014) 113(6):624-9. doi: 10.1016/j.anai.2014.08.004

22. Burk CM, Dellon ES, Steele PH, Virkud YV, Kulis M, Burks AW, et al. Eosinophilic esophagitis during peanut oral immunotherapy with omalizumab. J Allergy Clin Immunol Pract (2017) 5(2):498-501. doi: 10.1016/j.jaip.2016.11.010

23. Wright BL, Fernandez-Becker NQ, Kambham N, Purington N, Tupa D, Zhang W, et al. Baseline Gastrointestinal Eosinophilia Is Common in Oral Immunotherapy Subjects With IgE-Mediated Peanut Allergy. Front Immunol (2018) 9:2624. doi: 10.3389/fimmu.2018.02624

24. Wright BL, Fernandez-Becker NQ, Kambham N, Purington N, Cao S, Tupa D, et al. Gastrointestinal Eosinophil Responses in a Longitudinal, Randomized Trial of Peanut Oral Immunotherapy. Clin Gastroenterol Hepatol (2020). doi: 10.1016/j.cgh.2020.05.019

25. Spergel JM, Elci OU, Muir AB, Liacouras CA, Wilkins BJ, Burke D, et al. Efficacy of Epicutaneous Immunotherapy in Children With Milk-Induced Eosinophilic Esophagitis. Clin Gastroenterol Hepatol (2020) 18(2):328-36 e7. doi: 10.1016/j.cgh.2019.05.014

26. Kulis M, Saba K, Kim EH, Bird JA, Kamilaris N, Vickery BP, et al. Increased peanut-specific IgA levels in saliva correlate with food challenge outcomes after peanut sublingual immunotherapy. J Allergy Clin Immunol (2012) 129 (4):1159-62. doi: 10.1016/j.jaci.2011.11.045

27. Wright BL, Kulis M, Orgel KA, Burks AW, Dawson P, Henning AK, et al. Component-resolved analysis of IgA, IgE, and IgG4 during egg OIT identifies markers associated with sustained unresponsiveness. Allergy (2016) 71(11):1552-60. doi: 10.1111/all.12895 
28. Wright BL, Kulis M, Guo R, Orgel KA, Wolf WA, Burks AW, et al. Foodspecific IgG4 is associated with eosinophilic esophagitis. J Allergy Clin Immunol (2016) 138(4):1190-2 e3. doi: 10.1016/j.jaci.2016.02.024

29. Dellon ES, Guo R, McGee SJ, Hamilton DK, Nicolai E, Covington J, et al. A Novel Allergen-Specific Immune Signature-Directed Approach to Dietary Elimination in Eosinophilic Esophagitis. Clin Transl Gastroenterol (2019) 10 (12):e00099. doi: 10.14309/ctg.0000000000000099

30. Peterson K, Lin E, Saffari H, Qeadan F, Pyne A, Firszt R, et al. Food-specific antibodies in oesophageal secretions: association with trigger foods in eosinophilic esophagitis. Aliment Pharmacol Ther (2020) 52:997-1007. doi: 10.1111/apt.15879

31. Shoda T, Wen T, Aceves SS, Abonia JP, Atkins D, Bonis PA, et al. Eosinophilic oesophagitis endotype classification by molecular, clinical, and histopathological analyses: a cross-sectional study. Lancet Gastroenterol Hepatol (2018) 3(7):477-88. doi: 10.1016/S2468-1253(18) 30096-7

32. Dunn JLM, Shoda T, Caldwell JM, Wen T, Aceves SS, Collins MH, et al. Esophageal type 2 cytokine expression heterogeneity in eosinophilic esophagitis in a multisite cohort. J Allergy Clin Immunol (2020) 145 (6):1629-40 e4. doi: 10.1016/j.jaci.2020.01.051

33. Rothenberg ME, Hogan SP. The eosinophil. Annu Rev Immunol (2006) 24:147-74. doi: 10.1146/annurev.immunol.24.021605.090720

34. Legrand F, Cao Y, Wechsler JB, Zhu X, Zimmermann N, Rampertaap S, et al. Sialic acid-binding immunoglobulin-like lectin (Siglec) 8 in patients with eosinophilic disorders: Receptor expression and targeting using chimeric antibodies. J Allergy Clin Immunol (2019) 143(6):2227-37 e10. doi: 10.1016/ j.jaci.2018.10.066

35. Stein ML, Collins MH, Villanueva JM, Kushner JP, Putnam PE, Buckmeier BK, et al. Anti-IL-5 (mepolizumab) therapy for eosinophilic esophagitis. J Allergy Clin Immunol (2006) 118(6):1312-9. doi: 10.1016/j.jaci.2006.09.007

36. Straumann A, Conus S, Grzonka P, Kita H, Kephart G, Bussmann C, et al. Anti-interleukin-5 antibody treatment (mepolizumab) in active eosinophilic oesophagitis: a randomised, placebo-controlled, double-blind trial. Gut (2010) 59(1):21-30. doi: 10.1136/gut.2009.178558

37. Assa'ad AH, Gupta SK, Collins MH, Thomson M, Heath AT, Smith DA, et al. An antibody against IL-5 reduces numbers of esophageal intraepithelial eosinophils in children with eosinophilic esophagitis. Gastroenterology (2011) 141(5):1593-604. doi: 10.1053/j.gastro.2011.07.044

38. Spergel JM, Rothenberg ME, Collins MH, Furuta GT, Markowitz JE, Fuchs G,3, et al. Reslizumab in children and adolescents with eosinophilic esophagitis: results of a double-blind, randomized, placebo-controlled trial. J Allergy Clin Immunol (2012) 129(2):456-63, 63 e1-3. doi: 10.1016/ j.jaci.2011.11.044

39. Conus S, Straumann A, Bettler E, Simon HU. Mepolizumab does not alter levels of eosinophils, $\mathrm{T}$ cells, and mast cells in the duodenal mucosa in eosinophilic esophagitis. J Allergy Clin Immunol (2010) 126(1):175-7. doi: 10.1016/j.jaci.2010.04.029

40. Straumann A, Blanchard C, Radonjic-Hoesli S, Bussmann C, Hruz P, Safroneeva E, et al. A new eosinophilic esophagitis (EoE)-like disease without tissue eosinophilia found in EoE families. Allergy (2016) 71 (6):889-900. doi: 10.1111/all.12879

41. Lee JJ, Jacobsen EA, McGarry MP, Schleimer RP, Lee NA. Eosinophils in health and disease: the LIAR hypothesis. Clin Exp Allergy (2010) 40(4):56375. doi: 10.1111/j.1365-2222.2010.03484.x

42. Lee JJ, Jacobsen EA, Ochkur SI, McGarry MP, Condjella RM, Doyle AD, et al. Human versus mouse eosinophils: "that which we call an eosinophil, by any other name would stain as red". J Allergy Clin Immunol (2012) 130 (3):572-84. doi: 10.1016/j.jaci.2012.07.025

43. Hogan SP, Rosenberg HF, Moqbel R, Phipps S, Foster PS, Lacy P, et al. Eosinophils: biological properties and role in health and disease. Clin Exp Allergy (2008) 38(5):709-50. doi: 10.1111/j.1365-2222.2008.02958.x

44. Jacobsen EA, Helmers RA, Lee JJ, Lee NA. The expanding role(s) of eosinophils in health and disease. Blood (2012) 120(19):3882-90. doi: 10.1182/blood-2012-06-330845

45. Lee J, Rosenberg HF. Eosinophils in health and disease. 1st ed. London ; Waltham, MA: Elsevier/Academic Press (2013). p. 654. xxiii.

46. Gomes I, Mathur SK, Espenshade BM, Mori Y, Varga J, Ackerman SJ. Eosinophil-fibroblast interactions induce fibroblast IL-6 secretion and extracellular matrix gene expression: implications in fibrogenesis. J Allergy Clin Immunol (2005) 116(4):796-804. doi: 10.1016/j.jaci.2005.06.031

47. Del Pozo V, De Andres B, Martin E, Maruri N, Zubeldia JM, Palomino P, et al. Murine eosinophils and IL-1: alpha IL-1 mRNA detection by in situ hybridization. Production and release of IL-1 from peritoneal eosinophils. J Immunol (1990) 144(8):3117-22.

48. Weller PF, Rand TH, Barrett T, Elovic A, Wong DT, Finberg RW. Accessory cell function of human eosinophils. HLA-DR-dependent, MHC-restricted antigen-presentation and IL-1 alpha expression. J Immunol (1993) 150 (6):2554-62.

49. Blanchard C, Stucke EM, Rodriguez-Jimenez B, Burwinkel K, Collins MH, Ahrens A, et al. A striking local esophageal cytokine expression profile in eosinophilic esophagitis. J Allergy Clin Immunol (2011) 127(1):208-17, 17 e1-7. doi: 10.1016/j.jaci.2010.10.039

50. Jung Y, Wen T, Mingler MK, Caldwell JM, Wang YH, Chaplin DD, et al. ILlbeta in eosinophil-mediated small intestinal homeostasis and $\operatorname{IgA}$ production. Mucosal Immunol (2015) 8(4):930-42. doi: 10.1038/mi.2014.123

51. Arias A, Vicario M, Bernardo D, Olalla JM, Fortea M, Montalban-Arques A, et al. Toll-like receptors-mediated pathways activate inflammatory responses in the esophageal mucosa of adult eosinophilic esophagitis. Clin Transl Gastroenterol (2018) 9(4):147. doi: 10.1038/s41424-018-0017-4

52. Muir AB, Lim DM, Benitez AJ, Modayur Chandramouleeswaran P, Lee AJ, Ruchelli ED, et al. Esophageal epithelial and mesenchymal cross-talk leads to features of epithelial to mesenchymal transition in vitro. Exp Cell Res (2013) 319(6):850-9. doi: 10.1016/j.yexcr.2012.12.002

53. Sugawara R, Lee EJ, Jang MS, Jeun EJ, Hong CP, Kim JH, et al. Small intestinal eosinophils regulate Th17 cells by producing IL-1 receptor antagonist. J Exp Med (2016) 213(4):555-67. doi: 10.1084/jem.20141388

54. Kita H, Ohnishi T, Okubo Y, Weiler D, Abrams JS, Gleich GJ. Granulocyte/ macrophage colony-stimulating factor and interleukin 3 release from human peripheral blood eosinophils and neutrophils. J Exp Med (1991) 174(3):7458. doi: 10.1084/jem.174.3.745

55. Nakajima H, Gleich GJ, Kita H. Constitutive production of IL-4 and IL-10 and stimulated production of IL-8 by normal peripheral blood eosinophils. J Immunol (1996) 156(12):4859-66.

56. Broide DH, Paine MM, Firestein GS. Eosinophils express interleukin 5 and granulocyte macrophage-colony-stimulating factor mRNA at sites of allergic inflammation in asthmatics. J Clin Invest (1992) 90(4):1414-24. doi: 10.1172/JCI116008

57. Desreumaux P, Janin A, Colombel JF, Prin L, Plumas J, Emilie D, et al. Interleukin 5 messenger RNA expression by eosinophils in the intestinal mucosa of patients with coeliac disease. J Exp Med (1992) 175(1):293-6. doi: 10.1084/jem.175.1.293

58. Hamid Q, Barkans J, Meng Q, Ying S, Abrams JS, Kay AB, et al. Human eosinophils synthesize and secrete interleukin-6, in vitro. Blood (1992) 80 (6):1496-501. doi: 10.1182/blood.V80.6.1496.1496

59. Chu VT, Frohlich A, Steinhauser G, Scheel T, Roch T, Fillatreau S, et al. Eosinophils are required for the maintenance of plasma cells in the bone marrow. Nat Immunol (2011) 12(2):151-9. doi: 10.1038/ni.1981

60. Braun RK, Franchini M, Erard F, Rihs S, De Vries IJ, Blaser K, et al. Human peripheral blood eosinophils produce and release interleukin- 8 on stimulation with calcium ionophore. Eur J Immunol (1993) 23(4):956-60. doi: 10.1002/eji.1830230429

61. Cherry WB, Yoon J, Bartemes KR, Iijima K, Kita H. A novel IL-1 family cytokine, IL-33, potently activates human eosinophils. J Allergy Clin Immunol (2008) 121(6):1484-90. doi: 10.1016/j.jaci.2008.04.005

62. Cheung PF, Wong CK, Lam CW. Molecular mechanisms of cytokine and chemokine release from eosinophils activated by IL-17A, IL-17F, and IL-23: implication for Th17 lymphocytes-mediated allergic inflammation. J Immunol (2008) 180(8):5625-35. doi: 10.4049/jimmunol.180.8.5625

63. Otani IM, Anilkumar AA, Newbury RO, Bhagat M, Beppu LY, Dohil R, et al. Anti-IL-5 therapy reduces mast cell and IL-9 cell numbers in pediatric patients with eosinophilic esophagitis. J Allergy Clin Immunol (2013) 131 (6):1576-82. doi: 10.1016/j.jaci.2013.02.042

64. Doshi A, Khamishon R, Rawson R, Duong L, Dohil L, Myers SJ, et al. Interleukin 9 Alters Epithelial Barrier and E-cadherin in Eosinophilic Esophagitis. J Pediatr Gastroenterol Nutr (2019) 68(2):225-31. doi: 10.1097/MPG.0000000000002144 
65. Takeda K, Shiraishi Y, Ashino S, Han J, Jia Y, Wang M, et al. Eosinophils contribute to the resolution of lung-allergic responses following repeated allergen challenge. $J$ Allergy Clin Immunol (2015) 135(2):451-60. doi: 10.1016/j.jaci.2014.08.014

66. Lu S, Herzlinger M, Cao W, Noble L, Yang D, Shapiro J, et al. Utility of 15 (S)-HETE as a Serological Marker for Eosinophilic Esophagitis. Sci Rep (2018) 8(1):14498. doi: 10.1038/s41598-018-32944-8

67. Aceves SS, Ackerman SJ. Relationships between eosinophilic inflammation, tissue remodeling, and fibrosis in eosinophilic esophagitis. Immunol Allergy Clin North Am (2009) 29(1):197-211, xiii-xiv. doi: 10.1016/j.iac.2008.10.003

68. Mishra A, Rothenberg ME. Intratracheal IL-13 induces eosinophilic esophagitis by an IL-5, eotaxin-1, and STAT6-dependent mechanism. Gastroenterology (2003) 125(5):1419-27. doi: 10.1016/j.gastro.2003.07.007

69. Blanchard C, Mingler MK, Vicario M, Abonia JP, Wu YY, Lu TX, et al. IL-13 involvement in eosinophilic esophagitis: transcriptome analysis and reversibility with glucocorticoids. J Allergy Clin Immunol (2007) 120 (6):1292-300. doi: 10.1016/j.jaci.2007.10.024

70. Jacobsen EA, Doyle AD, Colbert DC, Zellner KR, Protheroe CA, LeSuer WE, et al. Differential activation of airway eosinophils induces IL-13-mediated allergic Th2 pulmonary responses in mice. Allergy (2015) 70(9):1148-59. doi: $10.1111 /$ all. 12655

71. Rochman M, Travers J, Abonia JP, Caldwell JM, Rothenberg ME. Synaptopodin is upregulated by IL-13 in eosinophilic esophagitis and regulates esophageal epithelial cell motility and barrier integrity. JCI Insight (2017) 2(20):e96789. doi: 10.1172/jci.insight.96789

72. Sherrill JD, Kc K, Wu D, Djukic Z, Caldwell JM, Stucke EM, et al. Desmoglein-1 regulates esophageal epithelial barrier function and immune responses in eosinophilic esophagitis. Mucosal Immunol (2014) 7(3):718-29. doi: $10.1038 / \mathrm{mi} .2013 .90$

73. Zeng C, Vanoni S, Wu D, Caldwell JM, Wheeler JC, Arora K, et al. Solute carrier family 9, subfamily A, member 3 (SLC9A3)/sodium-hydrogen exchanger member 3 (NHE3) dysregulation and dilated intercellular spaces in patients with eosinophilic esophagitis. J Allergy Clin Immunol (2018) 142(6):1843-55. doi: 10.1016/j.jaci.2018.03.017

74. Guerra ES, Lee CK, Specht CA, Yadav B, Huang H, Akalin A, et al. Central Role of IL-23 and IL-17 Producing Eosinophils as Immunomodulatory Effector Cells in Acute Pulmonary Aspergillosis and Allergic Asthma. PloS Pathog (2017) 13(1):e1006175. doi: 10.1371/journal.ppat.1006175

75. Niranjan R, Rajavelu P, Ventateshaiah SU, Shukla JS, Zaidi A, Mariswamy SJ, et al. Involvement of interleukin-18 in the pathogenesis of human eosinophilic esophagitis. Clin Immunol (2015) 157(2):103-13. doi: 10.1016/j.clim.2015.01.007

76. Dutt P, Shukla JS, Ventateshaiah SU, Mariswamy SJ, Mattner J, Shukla A, et al. Allergen-induced interleukin-18 promotes experimental eosinophilic oesophagitis in mice. Immunol Cell Biol (2015) 93(10):849-57. doi: 10.1038/ icb.2015.30

77. Verma AK, Kandikattu HK, Manohar M, Shukla A, Upparahalli Venkateshaiah S, Zhu X, et al. Intestinal overexpression of IL-18 promotes eosinophils-mediated allergic disorders. Immunology (2019) 157 (2):110-21. doi: 10.1111/imm.13051

78. Gatault S, Delbeke M, Driss V, Sarazin A, Dendooven A, Kahn JE, et al. IL-18 Is Involved in Eosinophil-Mediated Tumoricidal Activity against a Colon Carcinoma Cell Line by Upregulating LFA-1 and ICAM-1. J Immunol (2015) 195(5):2483-92. doi: 10.4049/jimmunol.1402914

79. Simon D, Radonjic-Hosli S, Straumann A, Yousefi S, Simon HU. Active eosinophilic esophagitis is characterized by epithelial barrier defects and eosinophil extracellular trap formation. Allergy (2015) 70(4):443-52. doi: 10.1111/all.12570

80. Terrier B, Bieche I, Maisonobe T, Laurendeau I, Rosenzwajg M, Kahn JE, et al. Interleukin-25: a cytokine linking eosinophils and adaptive immunity in Churg-Strauss syndrome. Blood (2010) 116(22):4523-31. doi: 10.1182/ blood-2010-02-267542

81. Spencer LA, Szela CT, Perez SA, Kirchhoffer CL, Neves JS, Radke AL, et al. Human eosinophils constitutively express multiple Th1, Th2, and immunoregulatory cytokines that are secreted rapidly and differentially. J Leukoc Biol (2009) 85(1):117-23. doi: 10.1189/jlb.0108058

82. Gupta SK, Fitzgerald JF, Kondratyuk T, HogenEsch H. Cytokine expression in normal and inflamed esophageal mucosa: a study into the pathogenesis of allergic eosinophilic esophagitis. J Pediatr Gastroenterol Nutr (2006) 42 (1):22-6. doi: 10.1097/01.mpg.0000188740.38757.d2
83. Mulder DJ, Pooni A, Mak N, Hurlbut DJ, Basta S, Justinich CJ. Antigen presentation and MHC class II expression by human esophageal epithelial cells: role in eosinophilic esophagitis. Am J Pathol (2011) 178(2):744-53. doi: 10.1016/j.ajpath.2010.10.027

84. Costa JJ, Matossian K, Resnick MB, Beil WJ, Wong DT, Gordon JR, et al. Human eosinophils can express the cytokines tumor necrosis factor-alpha and macrophage inflammatory protein-1 alpha. J Clin Invest (1993) 91 (6):2673-84. doi: 10.1172/JCI116506

85. Finotto S, Ohno I, Marshall JS, Gauldie J, Denburg JA, Dolovich J, et al. TNF-alpha production by eosinophils in upper airways inflammation (nasal polyposis). J Immunol (1994) 153(5):2278-89.

86. Puxeddu I, Berkman N, Ribatti D, Bader R, Haitchi HM, Davies DE, et al. Osteopontin is expressed and functional in human eosinophils. Allergy (2010) 65(2):168-74. doi: 10.1111/j.1398-9995.2009.02148.x

87. Matsumoto K, Fukuda S, Nakamura Y, Saito H. Amphiregulin production by human eosinophils. Int Arch Allergy Immunol (2009) 149 Suppl 1:39-44. doi: $10.1159 / 000210652$

88. Chu VT, Beller A, Rausch S, Strandmark J, Zanker M, Arbach O, et al. Eosinophils promote generation and maintenance of immunoglobulin-Aexpressing plasma cells and contribute to gut immune homeostasis. Immunity (2014) 40(4):582-93. doi: 10.1016/j.immuni.2014.02.014

89. Hartman M, Piliponsky AM, Temkin V, Levi-Schaffer F. Human peripheral blood eosinophils express stem cell factor. Blood (2001) 97(4):1086-91. doi: 10.1182/blood.V97.4.1086

90. Arias A, Lucendo AJ, Martinez-Fernandez P, Gonzalez-Castro AM, Fortea M, Gonzalez-Cervera J, et al. Dietary treatment modulates mast cell phenotype, density, and activity in adult eosinophilic oesophagitis. Clin Exp Allergy (2016) 46(1):78-91. doi: 10.1111/cea.12504

91. Wong DT, Weller PF, Galli SJ, Elovic A, Rand TH, Gallagher GT, et al. Human eosinophils express transforming growth factor alpha. J Exp Med (1990) 172(3):673-81. doi: 10.1084/jem.172.3.673

92. Aceves SS, Newbury RO, Dohil R, Bastian JF, Broide DH. Esophageal remodeling in pediatric eosinophilic esophagitis. J Allergy Clin Immunol (2007) 119(1):206-12. doi: 10.1016/j.jaci.2006.10.016

93. Kagalwalla AF, Akhtar N, Woodruff SA, Rea BA, Masterson JC, Mukkada V, et al. Eosinophilic esophagitis: epithelial mesenchymal transition contributes to esophageal remodeling and reverses with treatment. J Allergy Clin Immunol (2012) 129(5):1387-96 e7. doi: 10.1016/j.jaci.2012.03.005

94. Wong DT, Elovic A, Matossian K, Nagura N, McBride J, Chou MY, et al. Eosinophils from patients with blood eosinophilia express transforming growth factor beta 1. Blood (1991) 78(10):2702-7. doi: 10.1182/blood.V78.10.2702.2702

95. Levi-Schaffer F, Garbuzenko E, Rubin A, Reich R, Pickholz D, Gillery P, et al. Human eosinophils regulate human lung- and skin-derived fibroblast properties in vitro: a role for transforming growth factor beta (TGF-beta). Proc Natl Acad Sci U.S.A. (1999) 96(17):9660-5. doi: 10.1073/pnas.96.17.9660

96. Moqbel R, Hamid Q, Ying S, Barkans J, Hartnell A, Tsicopoulos A, et al. Expression of mRNA and immunoreactivity for the granulocyte/ macrophage colony-stimulating factor in activated human eosinophils. J Exp Med (1991) 174(3):749-52. doi: 10.1084/jem.174.3.749

97. Mann A, Breuhahn K, Schirmacher P, Blessing M. Keratinocyte-derived granulocyte-macrophage colony stimulating factor accelerates wound healing: Stimulation of keratinocyte proliferation, granulation tissue formation, and vascularization. J Invest Dermatol (2001) 117(6):1382-90. doi: 10.1046/j.0022-202x.2001.01600.x

98. McNamee EN, Biette KA, Hammer J, Harris R, Miyazawa H, Lee JJ, et al. Targeting granulocyte-macrophage colony-stimulating factor in epithelial and vascular remodeling in experimental eosinophilic esophagitis. Allergy (2017) 72(8):1232-42. doi: 10.1111/all.13105

99. Persad R, Huynh HQ, Hao L, Ha JR, Sergi C, Srivastava R, et al. Angiogenic remodeling in pediatric EoE is associated with increased levels of VEGF-A, angiogenin, IL-8, and activation of the TNF-alpha-NFkappaB pathway. J Pediatr Gastroenterol Nutr (2012) 55(3):251-60. doi: 10.1097/MPG.0b013e31824b6391

100. Horiuchi T, Weller PF. Expression of vascular endothelial growth factor by human eosinophils: upregulation by granulocyte macrophage colonystimulating factor and interleukin-5. Am J Respir Cell Mol Biol (1997) 17 (1):70-7. doi: 10.1165/ajrcmb.17.1.2796

101. Hoshino M, Nakamura Y, Hamid QA. Gene expression of vascular endothelial growth factor and its receptors and angiogenesis in bronchial 
asthma. J Allergy Clin Immunol (2001) 107(6):1034-8. doi: 10.1067/ mai.2001.115626

102. Huang JJ, Joh JW, Fuentebella J, Patel A, Nguyen T, Seki S, et al. Eotaxin and FGF enhance signaling through an extracellular signal-related kinase (ERK)dependent pathway in the pathogenesis of Eosinophilic esophagitis. Allergy Asthma Clin Immunol (2010) 6(1):25. doi: 10.1186/1710-1492-6-25

103. Stenfeldt AL, Wenneras C. Danger signals derived from stressed and necrotic epithelial cells activate human eosinophils. Immunology (2004) 112(4):60514. doi: 10.1111/j.1365-2567.2004.01906.x

104. Micera A, Vigneti E, Pickholtz D, Reich R, Pappo O, Bonini S, et al. Nerve growth factor displays stimulatory effects on human skin and lung fibroblasts, demonstrating a direct role for this factor in tissue repair. Proc Natl Acad Sci U.S.A. (2001) 98(11):6162-7. doi: 10.1073/pnas.101130898

105. Solomon A, Aloe L, Pe'er J, Frucht-Pery J, Bonini S, Bonini S, et al. Nerve growth factor is preformed in and activates human peripheral blood eosinophils. J Allergy Clin Immunol (1998) 102(3):454-60. doi: 10.1016/ S0091-6749(98)70135-6

106. Powell PP, Klagsbrun M, Abraham JA, Jones RC. Eosinophils expressing heparin-binding EGF-like growth factor mRNA localize around lung microvessels in pulmonary hypertension. Am J Pathol (1993) 143(3):784-93.

107. Dyer KD, Percopo CM, Xie Z, Yang Z, Kim JD, Davoine F, et al. Mouse and human eosinophils degranulate in response to platelet-activating factor (PAF) and lysoPAF via a PAF-receptor-independent mechanism: evidence for a novel receptor. J Immunol (2010) 184(11):6327-34. doi: 10.4049/jimmunol.0904043

108. Aliakbari J, Sreedharan SP, Turck CW, Goetzl EJ. Selective localization of vasoactive intestinal peptide and substance $\mathrm{P}$ in human eosinophils. Biochem Biophys Res Commun (1987) 148(3):1440-5. doi: 10.1016/S0006-291X(87) 80293-0

109. Verma AK, Manohar M, Venkateshaiah SU, Blecker U, Collins MH, Mishra A. Role of Vasoactive Intestinal Peptide in Promoting the Pathogenesis of Eosinophilic Esophagitis (EoE). Cell Mol Gastroenterol Hepatol (2018) 5 (1):99-100 e7. doi: 10.1016/j.jcmgh.2017.09.006

110. Driss V, Legrand F, Hermann E, Loiseau S, Guerardel Y, Kremer L, et al. TLR2dependent eosinophil interactions with mycobacteria: role of alpha-defensins. Blood (2009) 113(14):3235-44. doi: 10.1182/blood-2008-07-166595

111. Khatun A, Sakurai M, Okada K, Sakai Y, Morimoto M. Detection of alphadefensin in eosinophils in helminth-infected mouse model. J Vet Med Sci (2018) 80(12):1887-94. doi: 10.1292/jvms.18-0601

112. Hoshino M, Takahashi M, Aoike N. Expression of vascular endothelial growth factor, basic fibroblast growth factor, and angiogenin immunoreactivity in asthmatic airways and its relationship to angiogenesis. J Allergy Clin Immunol (2001) 107(2):295-301. doi: 10.1067/mai.2001.111928

113. Kishimoto K, Liu S, Tsuji T, Olson KA, Hu GF. Endogenous angiogenin in endothelial cells is a general requirement for cell proliferation and angiogenesis. Oncogene (2005) 24(3):445-56. doi: 10.1038/sj.onc.1208223

114. Okada S, Kita H, George TJ, Gleich GJ, Leiferman KM. Migration of eosinophils through basement membrane components in vitro: role of matrix metalloproteinase-9. Am J Respir Cell Mol Biol (1997) 17(4):51928. doi: 10.1165/ajrcmb.17.4.2877

115. Esnault S, Kelly EA, Johnson SH, DeLain LP, Haedt MJ, Noll AL, et al. Matrix Metalloproteinase-9-Dependent Release of IL-1beta by Human Eosinophils. Mediators Inflammation (2019) 2019:7479107. doi: 10.1155/2019/7479107

116. Kobayashi M, Naomoto Y, Nobuhisa T, Okawa T, Takaoka M, Shirakawa Y, et al. Heparanase regulates esophageal keratinocyte differentiation through nuclear translocation and heparan sulfate cleavage. Differentiation (2006) 74 (5):235-43. doi: 10.1111/j.1432-0436.2006.00072.x

117. Zcharia E, Zilka R, Yaar A, Yacoby-Zeevi O, Zetser A, Metzger S, et al. Heparanase accelerates wound angiogenesis and wound healing in mouse and rat models. FASEB J (2005) 19(2):211-21. doi: 10.1096/fj.04-1970com

118. Temkin V, Aingorn H, Puxeddu I, Goldshmidt O, Zcharia E, Gleich GJ, et al. Eosinophil major basic protein: first identified natural heparanase-inhibiting protein. J Allergy Clin Immunol (2004) 113(4):703-9. doi: 10.1016/j.jaci.2003.11.038

119. Zeiger RS, Colten HR. Histaminase release from human eosinophils. J Immunol (1977) 118(2):540-3.

120. Wen T, Stucke EM, Grotjan TM, Kemme KA, Abonia JP, Putnam PE, et al. Molecular diagnosis of eosinophilic esophagitis by gene expression profiling. Gastroenterology (2013) 145(6):1289-99. doi: 10.1053/j.gastro.2013.08.046
121. MacMillan DK, Hill E, Sala A, Sigal E, Shuman T, Henson PM, et al. Eosinophil 15lipoxygenase is a leukotriene A4 synthase. J Biol Chem (1994) 269(43):26663-8.

122. Isobe $\mathrm{Y}$, Arita M, Matsueda S, Iwamoto R, Fujihara T, Nakanishi H, et al. Identification and structure determination of novel anti-inflammatory mediator resolvin E3, 17,18-dihydroxyeicosapentaenoic acid. J Biol Chem (2012) 287(13):10525-34. doi: 10.1074/jbc.M112.340612

123. Hui Y, Chen S, Lombardo KA, Resnick MB, Mangray S, Matoso A. ALOX15 Immunohistochemistry Aids in the Diagnosis of Eosinophilic Esophagitis on Pauci-eosinophilic Biopsies in Children. Pediatr Dev Pathol (2017) 20 (5):375-80. doi: 10.1177/1093526617693106

124. Odemuyiwa SO, Ghahary A, Li Y, Puttagunta L, Lee JE, Musat-Marcu S, et al. Cutting edge: human eosinophils regulate $\mathrm{T}$ cell subset selection through indoleamine 2,3-dioxygenase. J Immunol (2004) 173(10):5909-13. doi: 10.4049/jimmunol.173.10.5909

125. Prendergast GC, Smith C, Thomas S, Mandik-Nayak L, Laury-Kleintop L, Metz R, et al. Indoleamine 2,3-dioxygenase pathways of pathogenic inflammation and immune escape in cancer. Cancer Immunol Immunother (2014) 63(7):721-35. doi: 10.1007/s00262-014-1549-4

126. Mulder DJ, Pacheco I, Hurlbut DJ, Mak N, Furuta GT, MacLeod RJ, et al. FGF9-induced proliferative response to eosinophilic inflammation in oesophagitis. Gut (2009) 58(2):166-73. doi: 10.1136/gut.2008.157628

127. Pegorier S, Wagner LA, Gleich GJ, Pretolani M. Eosinophil-derived cationic proteins activate the synthesis of remodeling factors by airway epithelial cells. J Immunol (2006) 177(7):4861-9. doi: 10.4049/jimmunol.177.7.4861

128. Furuta GT, Nieuwenhuis EE, Karhausen J, Gleich G, Blumberg RS, Lee JJ, et al. Eosinophils alter colonic epithelial barrier function: role for major basic protein. Am J Physiol Gastrointest Liver Physiol (2005) 289(5):G890-7. doi: 10.1152/ajpgi.00015.2005

129. O'Donnell MC, Ackerman SJ, Gleich GJ, Thomas LL. Activation of basophil and mast cell histamine release by eosinophil granule major basic protein. J Exp Med (1983) 157(6):1981-91. doi: 10.1084/jem.157.6.1981

130. Gleich GJ, Adolphson CR, Leiferman KM. The biology of the eosinophilic leukocyte. Annu Rev Med (1993) 44:85-101. doi: 10.1146/annurev.me.44.020193.000505

131. Dellon ES, Speck O, Woodward K, Covey S, Rusin S, Gebhart JH, et al. Markers of eosinophilic inflammation for diagnosis of eosinophilic esophagitis and proton pump inhibitor-responsive esophageal eosinophilia: a prospective study. Clin Gastroenterol Hepatol (2014) 12(12):2015-22. doi: 10.1016/j.cgh.2014.06.019

132. Furuta GT, Kagalwalla AF, Lee JJ, Alumkal P, Maybruck BT, Fillon S, et al. The oesophageal string test: a novel, minimally invasive method measures mucosal inflammation in eosinophilic oesophagitis. Gut (2013) 62(10):1395405. doi: 10.1136/gutjnl-2012-303171

133. Martin LJ, Franciosi JP, Collins MH, Abonia JP, Lee JJ, Hommel KA, et al. Pediatric Eosinophilic Esophagitis Symptom Scores (PEESS v2.0) identify histologic and molecular correlates of the key clinical features of disease. $J$ Allergy Clin Immunol (2015) 135(6):1519-28 e8. doi: 10.1016/j.jaci.2015.03.004

134. Wright BL, Doyle AD, Shim KP, Pai RK, Barshow SM, Horsley-Silva JL, et al. Image Analysis of Eosinophil Peroxidase Immunohistochemistry for Diagnosis of Eosinophilic Esophagitis. Dig Dis Sci (2020). doi: 10.1007/ s10620-020-06230-5

135. Bystrom J, Amin K, Bishop-Bailey D. Analysing the eosinophil cationic protein-a clue to the function of the eosinophil granulocyte. Respir Res (2011) 12:10. doi: 10.1186/1465-9921-12-10

136. Yang D, Chen Q, Su SB, Zhang P, Kurosaka K, Caspi RR, et al. Eosinophilderived neurotoxin acts as an alarmin to activate the TLR2-MyD88 signal pathway in dendritic cells and enhances Th2 immune responses. J Exp Med (2008) 205(1):79-90. doi: 10.1084/jem.20062027

137. Yang D, Rosenberg HF, Chen Q, Dyer KD, Kurosaka K, Oppenheim JJ. Eosinophil-derived neurotoxin (EDN), an antimicrobial protein with chemotactic activities for dendritic cells. Blood (2003) 102(9):3396-403. doi: 10.1182/blood-2003-01-0151

138. Acharya KR, Ackerman SJ. Eosinophil granule proteins: form and function. J Biol Chem (2014) 289(25):17406-15. doi: 10.1074/jbc.R113.546218

139. Grozdanovic MM, Doyle CB, Liu L, Maybruck BT, Kwatia MA, Thiyagarajan $\mathrm{N}$, et al. Charcot-Leyden crystal protein/galectin-10 interacts with cationic ribonucleases and is required for eosinophil granulogenesis. J Allergy Clin Immunol (2020) 146(2):377-89 e10. doi: 10.1016/j.jaci.2020.01.013 
140. Persson EK, Verstraete K, Heyndrickx I, Gevaert E, Aegerter H, Percier JM, et al. Protein crystallization promotes type 2 immunity and is reversible by antibody treatment. Science (2019) 364(6442):eaaw4295. doi: 10.1126/ science.aaw4295

141. Lee T, Lenihan DJ, Malone B, Roddy LL, Wasserman SI. Increased biosynthesis of platelet-activating factor in activated human eosinophils. J Biol Chem (1984) 259(9):5526-30.

142. Foegh ML, Maddox YT, Ramwell PW. Human peritoneal eosinophils and formation of arachidonate cyclooxygenase products. Scand J Immunol (1986) 23(5):599-603. doi: 10.1111/j.1365-3083.1986.tb01993.x

143. Lexmond WS, Pardo M, Rooney K, Goettel JA, Snapper SB, Yen EH, et al. Elevated levels of leukotriene C4 synthase mRNA distinguish a subpopulation of eosinophilic oesophagitis patients. Clin Exp Allergy (2013) 43(8):902-13. doi: 10.1111/cea.12146

144. Walsh GM, Hartnell A, Moqbel R, Cromwell O, Nagy L, Bradley B, et al. Receptor expression and functional status of cultured human eosinophils derived from umbilical cord blood mononuclear cells. Blood (1990) 76 (1):105-11. doi: 10.1182/blood.V76.1.105.105

145. Luna-Gomes T, Magalhaes KG, Mesquita-Santos FP, Bakker-Abreu I, Samico RF, Molinaro R, et al. Eosinophils as a novel cell source of prostaglandin D2: autocrine role in allergic inflammation. J Immunol (2011) 187(12):6518-26. doi: 10.4049/jimmunol.1101806

146. Parsons WG,3, Roberts LJ,2. Transformation of prostaglandin D2 to isomeric prostaglandin F2 compounds by human eosinophils: a potential mast cell-eosinophil interaction. Adv Prostaglandin Thromboxane Leukot Res (1989) 19:499-502.

147. Zhang S, Wu X, Yu S. Prostaglandin D2 receptor D-type prostanoid receptor 2 mediates eosinophil trafficking into the esophagus. Dis Esophagus (2014) 27(6):601-6. doi: 10.1111/dote.12118

148. Yamada T, Tani Y, Nakanishi H, Taguchi R, Arita M, Arai H. Eosinophils promote resolution of acute peritonitis by producing proresolving mediators in mice. FASEB J (2011) 25(2):561-8. doi: 10.1096/fj.10-170027

149. Schwab JM, Chiang N, Arita M, Serhan CN. Resolvin E1 and protectin D1 activate inflammation-resolution programmes. Nature (2007) 447 (7146):869-74. doi: 10.1038/nature05877

150. Jacobsen EA, Ochkur SI, Pero RS, Taranova AG, Protheroe CA, Colbert DC, et al. Allergic pulmonary inflammation in mice is dependent on eosinophilinduced recruitment of effector T cells. J Exp Med (2008) 205(3):699-710. doi: 10.1084/jem.20071840

151. Liu LY, Bates ME, Jarjour NN, Busse WW, Bertics PJ, Kelly EA. Generation of Th1 and Th2 chemokines by human eosinophils: evidence for a critical role of TNF-alpha. J Immunol (2007) 179(7):4840-8. doi: 10.4049/ jimmunol.179.7.4840

152. Lim KG, Wan HC, Resnick M, Wong DT, Cruikshank WW, Kornfeld H, et al. Human eosinophils release the lymphocyte and eosinophil active cytokines, RANTES and lymphocyte chemoattractant factor. Int Arch Allergy Immunol (1995) 107(1-3):342. doi: 10.1159/000237023

153. Johnsson M, Bove M, Bergquist H, Olsson M, Fornwall S, Hassel K, et al. Distinctive blood eosinophilic phenotypes and cytokine patterns in eosinophilic esophagitis, inflammatory bowel disease and airway allergy. J Innate Immun (2011) 3(6):594-604. doi: 10.1159/000331326

154. Nakajima T, Yamada H, Iikura M, Miyamasu M, Izumi S, Shida H, et al. Intracellular localization and release of eotaxin from normal eosinophils. FEBS Lett (1998) 434(3):226-30. doi: 10.1016/S0014-5793(98)00863-1

155. Persson T, Monsef N, Andersson P, Bjartell A, Malm J, Calafat J, et al. Expression of the neutrophil-activating CXC chemokine ENA-78/CXCL5 by human eosinophils. Clin Exp Allergy (2003) 33(4):531-7. doi: 10.1046/j.13652222.2003.01609.x

156. O'Shea KM, Rochman M, Shoda T, Zimmermann N, Caldwell J, Rothenberg ME. Eosinophilic esophagitis with extremely high esophageal eosinophil counts. J Allergy Clin Immunol (2020). doi: 10.1016/j.jaci.2020.05.045

157. Lee PJ, Zhang X, Shan P, Ma B, Lee CG, Homer RJ, et al. ERK1/2 mitogenactivated protein kinase selectively mediates IL-13-induced lung inflammation and remodeling in vivo. J Clin Invest (2006) 116(1):163-73. doi: $10.1172 /$ JCI25711

158. Devalaraja RM, Nanney LB, Du J, Qian Q, Yu Y, Devalaraja MN, et al. Delayed wound healing in CXCR2 knockout mice. J Invest Dermatol (2000) 115(2):234-44. doi: 10.1046/j.1523-1747.2000.00034.x
159. Sayej WN, Menoret A, Maharjan AS, Fernandez M, Wang Z, Balarezo F, et al. Characterizing the inflammatory response in esophageal mucosal biopsies in children with eosinophilic esophagitis. Clin Transl Immunol (2016) 5(7):e88. doi: 10.1038/cti.2016.30

160. Izumi S, Hirai K, Miyamasu M, Takahashi Y, Misaki Y, Takaishi T, et al. Expression and regulation of monocyte chemoattractant protein-1 by human eosinophils. Eur J Immunol (1997) 27(4):816-24. doi: 10.1002/ eji.1830270404

161. Matsumoto K, Fukuda S, Hashimoto N, Saito H. Human eosinophils produce and release a novel chemokine, CCL23, in vitro. Int Arch Allergy Immunol (2011) 155 Suppl 1:34-9. doi: 10.1159/000327263

162. Oliveira SH, Taub DD, Nagel J, Smith R, Hogaboam CM, Berlin A, et al. Stem cell factor induces eosinophil activation and degranulation: mediator release and gene array analysis. Blood (2002) 100(13):4291-7. doi: 10.1182/ blood.V100.13.4291

163. Dajotoy T, Andersson P, Bjartell A, Lofdahl CG, Tapper H, Egesten A. Human eosinophils produce the T cell-attracting chemokines MIG and IP10 upon stimulation with IFN-gamma. J Leukoc Biol (2004) 76(3):685-91. doi: 10.1189/jlb.0803379

164. Reed CC, Wolf WA, Cotton CC, Rusin S, Perjar I, Hollyfield J, et al. Optimal Histologic Cutpoints for Treatment Response in Patients With Eosinophilic Esophagitis: Analysis of Data From a Prospective Cohort Study. Clin Gastroenterol Hepatol (2018) 16(2):226-33 e2. doi: 10.1016/j.cgh.2017.09.046

165. McBrien CN, Menzies-Gow A. The Biology of Eosinophils and Their Role in Asthma. Front Med (Lausanne) (2017) 4:93. doi: 10.3389/fmed.2017.00093

166. Jacobsen EA, Lee NA, Lee JJ. Re-defining the unique roles for eosinophils in allergic respiratory inflammation. Clin Exp Allergy (2014) 44(9):1119-36. doi: $10.1111 /$ cea.12358

167. Cheng E, Souza RF, Spechler SJ. Tissue remodeling in eosinophilic esophagitis. Am J Physiol Gastrointest Liver Physiol (2012) 303(11):G117587. doi: 10.1152/ajpgi.00313.2012

168. Aceves SS. Remodeling and fibrosis in chronic eosinophil inflammation. Dig Dis (2014) 32(1-2):15-21. doi: 10.1159/000357004

169. Simon D, Straumann A, Schoepfer AM, Simon HU. Current concepts in eosinophilic esophagitis. Allergo J Int (2017) 26(7):258-66. doi: 10.1007/s40629-017-0037-8

170. Clayton F, Peterson K. Eosinophilic Esophagitis: Pathophysiology and Definition. Gastrointest Endosc Clin N Am (2018) 28(1):1-14. doi: 10.1016/j.giec.2017.07.011

171. Rothenberg ME. Biology and treatment of eosinophilic esophagitis. Gastroenterology (2009) 137(4):1238-49. doi: 10.1053/j.gastro.2009.07.007

172. Davis BP, Rothenberg ME. Mechanisms of Disease of Eosinophilic Esophagitis. Annu Rev Pathol (2016) 11:365-93. doi: 10.1146/annurevpathol-012615-044241

173. Davis BP. Pathophysiology of Eosinophilic Esophagitis. Clin Rev Allergy Immunol (2018) 55(1):19-42. doi: 10.1007/s12016-017-8665-9

174. Blanchard C, Simon D, Schoepfer A, Straumann A, Simon HU. Eosinophilic esophagitis: unclear roles of IgE and eosinophils. J Intern Med (2017) 281 (5):448-57. doi: 10.1111/joim.12568

175. Muir AB, Wang JX, Nakagawa H. Epithelial-stromal crosstalk and fibrosis in eosinophilic esophagitis. J Gastroenterol (2019) 54(1):10-8. doi: 10.1007/ s00535-018-1498-3

176. Mjosberg JM, Trifari S, Crellin NK, Peters CP, van Drunen CM, Piet B, et al. Human IL-25- and IL-33-responsive type 2 innate lymphoid cells are defined by expression of CRTH2 and CD161. Nat Immunol (2011) 12(11):1055-62. doi: $10.1038 /$ ni.2104

177. Doherty TA, Baum R, Newbury RO, Yang T, Dohil R, Aquino M, et al. Group 2 innate lymphocytes (ILC2) are enriched in active eosinophilic esophagitis. J Allergy Clin Immunol (2015) 136(3):792-4 e3. doi: 10.1016/ j.jaci.2015.05.048

178. Blanchard C, Wang N, Stringer KF, Mishra A, Fulkerson PC, Abonia JP, et al. Eotaxin-3 and a uniquely conserved gene-expression profile in eosinophilic esophagitis. J Clin Invest (2006) 116(2):536-47. doi: 10.1172/JCI26679

179. Mishra A, Wang M, Pemmaraju VR, Collins MH, Fulkerson PC, Abonia JP, et al. Esophageal remodeling develops as a consequence of tissue specific IL5-induced eosinophilia. Gastroenterology (2008) 134(1):204-14. doi: 10.1053/j.gastro.2007.10.002

180. Masterson JC, McNamee EN, Hosford L, Capocelli KE, Ruybal J, Fillon SA, et al. Local hypersensitivity reaction in transgenic mice with squamous 
epithelial IL-5 overexpression provides a novel model of eosinophilic oesophagitis. Gut (2014) 63(1):43-53. doi: 10.1136/gutjnl-2012-303631

181. Schoepfer AM, Simko A, Bussmann C, Safroneeva E, Zwahlen M, Greuter T, et al. Eosinophilic Esophagitis: Relationship of Subepithelial Eosinophilic Inflammation With Epithelial Histology, Endoscopy, Blood Eosinophils, and Symptoms. Am J Gastroenterol (2018) 113(3):348-57. doi: 10.1038/ajg.2017.493

182. Hirano I. Clinical relevance of esophageal subepithelial activity in eosinophilic esophagitis. J Gastroenterol (2020) 55(3):249-60. doi: 10.1007/ s00535-019-01624-3

183. Yousefi S, Gold JA, Andina N, Lee JJ, Kelly AM, Kozlowski E, et al. Catapultlike release of mitochondrial DNA by eosinophils contributes to antibacterial defense. Nat Med (2008) 14(9):949-53. doi: 10.1038/nm.1855

184. Cliffe LJ, Humphreys NE, Lane TE, Potten CS, Booth C, Grencis RK. Accelerated intestinal epithelial cell turnover: a new mechanism of parasite expulsion. Science (5727) 2005) 308:1463-5. doi: 10.1126/science.1108661

185. Straumann A, Kristl J, Conus S, Vassina E, Spichtin HP, Beglinger C, et al. Cytokine expression in healthy and inflamed mucosa: probing the role of eosinophils in the digestive tract. Inflammation Bowel Dis (2005) 11(8):7206. doi: 10.1097/01.MIB.0000172557.39767.53

186. Mueller S, Aigner T, Neureiter D, Stolte M. Eosinophil infiltration and degranulation in oesophageal mucosa from adult patients with eosinophilic oesophagitis: a retrospective and comparative study on pathological biopsy. J Clin Pathol (2006) 59(11):1175-80. doi: 10.1136/jcp.2005.031922

187. Stolarski B, Kurowska-Stolarska M, Kewin P, Xu D, Liew FY. IL-33 exacerbates eosinophil-mediated airway inflammation. J Immunol (2010) 185(6):3472-80. doi: 10.4049/jimmunol.1000730

188. Kurowska-Stolarska M, Stolarski B, Kewin P, Murphy G, Corrigan CJ, Ying $\mathrm{S}$, et al. IL-33 amplifies the polarization of alternatively activated macrophages that contribute to airway inflammation. J Immunol (2009) 183(10):6469-77. doi: 10.4049/jimmunol.0901575

189. Bouffi C, Rochman M, Zust CB, Stucke EM, Kartashov A, Fulkerson PC, et al. IL-33 markedly activates murine eosinophils by an NF-kappaB-dependent mechanism differentially dependent upon an IL-4-driven autoinflammatory loop. J Immunol (2013) 191(8):4317-25. doi: 10.4049/jimmunol.1301465

190. Shik D, Moshkovits I, Karo-Atar D, Reichman H, Munitz A. Interleukin-33 requires CMRF35-like molecule-1 expression for induction of myeloid cell activation. Allergy (2014) 69(6):719-29. doi: 10.1111/all.12388

191. Patel AJ, Fuentebella J, Gernez Y, Nguyen T, Bass D, Berquist W, et al. Increased HLA-DR expression on tissue eosinophils in eosinophilic esophagitis. J Pediatr Gastroenterol Nutr (2010) 51(3):290-4. doi: 10.1097/ MPG.0b013e3181e083e7

192. Le-Carlson M, Seki S, Abarbanel D, Quiros A, Cox K, Nadeau KC. Markers of antigen presentation and activation on eosinophils and $\mathrm{T}$ cells in the esophageal tissue of patients with eosinophilic esophagitis. J Pediatr Gastroenterol Nutr (2013) 56(3):257-62. doi: 10.1097/MPG.0b013e3182758d49

193. Masterson JC, Biette KA, Hammer JA, Nguyen N, Capocelli KE, Saeedi BJ, et al. Epithelial HIF-1alpha/claudin-1 axis regulates barrier dysfunction in eosinophilic esophagitis. J Clin Invest (2019) 129(8):3224-35. doi: 10.1172/ JCI126744

194. Bolton SM, Kagalwalla AF, Arva NC, Wang MY, Amsden K, Melin-Aldana $\mathrm{H}$, et al. Mast Cell Infiltration Is Associated With Persistent Symptoms and Endoscopic Abnormalities Despite Resolution of Eosinophilia in Pediatric Eosinophilic Esophagitis. Am J Gastroenterol (2020) 115(2):224-33. doi: 10.14309/ajg.0000000000000474

195. Oyesola OO, Duque C, Huang LC, Larson EM, Fruh SP, Webb LM, et al. The Prostaglandin D2 Receptor CRTH2 Promotes IL-33-Induced ILC2 Accumulation in the Lung. J Immunol (2020) 204(4):1001-11. doi: 10.4049/jimmunol.1900745

196. Wen T, Aronow BJ, Rochman Y, Rochman M, Kc K, Dexheimer PJ, et al. Single-cell RNA sequencing identifies inflammatory tissue $\mathrm{T}$ cells in eosinophilic esophagitis. J Clin Invest (2019) 129(5):2014-28. doi: 10.1172/ JCI125917
197. Gleich GJ, Frigas E, Loegering DA, Wassom DL, Steinmuller D. Cytotoxic properties of the eosinophil major basic protein. J Immunol (1979) 123 (6):2925-7.

198. Flavahan NA, Slifman NR, Gleich GJ, Vanhoutte PM. Human eosinophil major basic protein causes hyperreactivity of respiratory smooth muscle. Role of the epithelium. Am Rev Respir Dis (1988) 138(3):685-8. doi: 10.1164/ ajrccm/138.3.685

199. Jacoby DB, Gleich GJ, Fryer AD. Human eosinophil major basic protein is an endogenous allosteric antagonist at the inhibitory muscarinic M2 receptor. J Clin Invest (1993) 91(4):1314-8. doi: 10.1172/JCI116331

200. Rochester CL, Ackerman SJ, Zheng T, Elias JA. Eosinophil-fibroblast interactions. Granule major basic protein interacts with IL-1 and transforming growth factor-beta in the stimulation of lung fibroblast IL-6type cytokine production. J Immunol (1996) 156(11):4449-56.

201. Davis BP, Stucke EM, Khorki ME, Litosh VA, Rymer JK, Rochman M, et al. Eosinophilic esophagitis-linked calpain 14 is an IL-13-induced protease that mediates esophageal epithelial barrier impairment. JCI Insight (2016) 1(4): e86355. doi: 10.1172/jci.insight. 86355

202. Rothenberg ME, Wen T, Greenberg A, Alpan O, Enav B, Hirano I, et al. Intravenous anti-IL-13 mAb QAX576 for the treatment of eosinophilic esophagitis. J Allergy Clin Immunol (2015) 135(2):500-7. doi: 10.1016/ j.jaci.2014.07.049

203. Hirano I, Collins MH, Assouline-Dayan Y, Evans L, Gupta S, Schoepfer AM, et al. RPC4046, a Monoclonal Antibody Against IL13, Reduces Histologic and Endoscopic Activity in Patients With Eosinophilic Esophagitis. Gastroenterology (2019) 156(3):592-603 e10. doi: 10.1053/j.gastro. 2018.10.051

204. Hirano I, Dellon ES, Hamilton JD, Collins MH, Peterson K, Chehade M, et al. Efficacy of Dupilumab in a Phase 2 Randomized Trial of Adults With Active Eosinophilic Esophagitis. Gastroenterology (2020) 158(1):111-22 e10. doi: 10.1053/j.gastro.2019.09.042

205. Mishra A, Hogan SP, Brandt EB, Rothenberg ME. An etiological role for aeroallergens and eosinophils in experimental esophagitis. J Clin Invest (2001) 107(1):83-90. doi: 10.1172/JCI10224

206. Zuo L, Fulkerson PC, Finkelman FD, Mingler M, Fischetti CA, Blanchard C, et al. IL-13 induces esophageal remodeling and gene expression by an eosinophil-independent, IL-13R alpha 2-inhibited pathway. J Immunol (2010) 185(1):660-9. doi: 10.4049/jimmunol.1000471

207. Doyle AD, Mukherjee M, LeSuer WE, Bittner TB, Pasha SM, Frere JJ, et al. Eosinophil-derived IL-13 promotes emphysema. Eur Respir J (2019) 53 (5):1801291. doi: 10.1183/13993003.01291-2018

208. Hashimoto S, Gon Y, Takeshita I, Maruoka S, Horie T. IL-4 and IL-13 induce myofibroblastic phenotype of human lung fibroblasts through c-Jun NH2terminal kinase-dependent pathway. J Allergy Clin Immunol (2001) 107 (6):1001-8. doi: 10.1067/mai.2001.114702

209. Verrecchia F, Mauviel A. Transforming growth factor-beta and fibrosis. World J Gastroenterol (2007) 13(22):3056-62. doi: 10.3748/wjg.v13.i22.3056

210. Beppu LY, Anilkumar AA, Newbury RO, Dohil R, Broide DH, Aceves SS. TGF-beta1-induced phospholamban expression alters esophageal smooth muscle cell contraction in patients with eosinophilic esophagitis. J Allergy Clin Immunol (2014) 134(5):1100-7 e4. doi: 10.1016/j.jaci.2014.04.004

Conflict of Interest: The authors declare that the research was conducted in the absence of any commercial or financial relationships that could be construed as a potential conflict of interest.

Copyright (c) 2020 Doyle, Masuda, Kita and Wright. This is an open-access article distributed under the terms of the Creative Commons Attribution License (CC BY). The use, distribution or reproduction in other forums is permitted, provided the original author(s) and the copyright owner(s) are credited and that the original publication in this journal is cited, in accordance with accepted academic practice. No use, distribution or reproduction is permitted which does not comply with these terms. 